\title{
Performance and Microbial Community Analysis of a Constructed Rapid Infiltration System at Different Depths
}

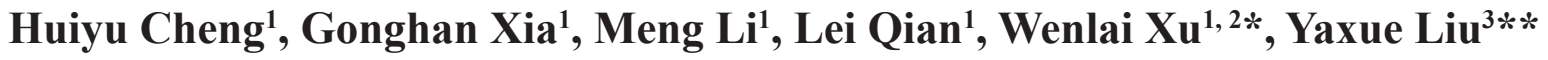 \\ ${ }^{1}$ State Key Laboratory of Geohazard Prevention and Geoenvironmental Protection, \\ Chengdu University of Technology, Chengdu, China \\ ${ }^{2}$ Department of International Environmental and Agricultural Science, Tokyo University of Agriculture \\ and Technology, Tokyo, Japan \\ ${ }^{3}$ Sichuan Contaminated Site Environmental Remediation Engineering Technology Center, Chengdu, China
}

Received: 15 September 2019

Accepted: 15 November 2019

\begin{abstract}
To study the removal performance of a constructed rapid infiltration (CRI) system and its microbial community characteristics, we took the demonstration project of a CRI system that has successfully operated for 15 years as an example, aiming to analyze the CRI system's removal performances for $\mathrm{COD}, \mathrm{NH}_{4}{ }^{+}-\mathrm{N}, \mathrm{TN}$ and TP. Meanwhile, high-throughput sequencing technology was used for the first time to study the microbial community diversity and structure in the CRI system. The results showed that the average removal efficiencies for COD and $\mathrm{NH}_{4}{ }^{+}-\mathrm{N}$ were $75.52 \%$ and $92.94 \%$, and the average removal efficiencies for TN and TP were respectively $39.74 \%$ and $42.78 \%$. High-throughput sequencing technology indicated that a variety of bacterial phyla were found in CRI's bacterial communities, including Bacteroidetes, Actinobacteria and Acidobacteria, among which Proteobacteria dominated. At the genus level, a spatial variation was illustrated for the diversity and structure of bacterial communities. The dominant genera on the surface layer $(0 \mathrm{~cm})$ of CRI were mainly Nocardioides, Sphingomonas, Bryobacter and other microorganisms that can degrade organic matter, and the dominant genera in the inside $(30-120 \mathrm{~cm})$ were mainly microorganisms that play an important role in removing nitrogen. This study provided a theoretical basis for the long-term operation of a CRI system.
\end{abstract}

Keywords: constructed rapid infiltration (CRI), wastewater treatment, high-throughput sequencing, microbial community

*e-mail: xuwenlai2012@cdut.cn

**e-mail: Liuyxsctsy@163.com 


\section{Introduction}

A constructed rapid infiltration (CRI) system is a new sewage treatment technology based on a traditional rapid infiltration (RI) system [1-2]. In this system, natural sand with excellent permeability and a certain amount of special filler replaced traditional natural soil layers of sewage rapid infiltration [3]. Therefore, CRI solved the problem of traditional land's low hydraulic loading of treatment and large area coverage; meanwhile, dry-wet alternate operation greatly improved the reoxygenation capability and the removal effect on pollutants [2].

The CRI system has the advantages of low cost, low energy consumption, high operation efficiency, simple and convenient management and protection [4]. It can be applied to the polluted river and rural domestic sewage treatment [4], and it has been widely applied to more than 10 provinces, cities and regions, including Beijing, Guangdong Province, Sichuan Province, Shangxi Province, Hongkong, etc. [6]. In Yunnan Province, Chao et al. [6] has studied the operational effect of utilizing CRI to treat pollutants entering Lake Dianchi through Daqing River, and the result showed that CRI has a strong removal effect and shock resistance capability for organisms. Wu et al. [8] carried out seasonal operational effect analysis on a $\mathrm{CRI}$ and biological wetland integration system and got the result that CRI can remove each pollutant in rural domestic sewage strongly, and the removal efficiency for COD, TN, and TP reached the highest in summer, at respectively $92.2 \%, 87.0 \%$ and $85.9 \%$. In addition, $\mathrm{Li}$ et al. [9] and Gao et al. [10] all got the result that the CRI system is capable of reducing the concentration of $\mathrm{COD}, \mathrm{NH}_{4}^{+}-\mathrm{N}, \mathrm{TN}$, and TP so as to adjust and recover domestic sewage effectively. However, some research has also indicated that CRI technology exposed some problems in the concrete operation process, such as easy blockage of fillers in the CRI tank [11], unstable nitrogen and phosphorus removal effect of the system [12]. Chen et al. [13] examined the domestic sewage treatment effect of a CRI system of Chongqing in winter and found that the effluent $\mathrm{COD}, \mathrm{NH}_{4}^{+}-\mathrm{N}$ and TP cannot reach the standard. This research took the CRI system with the largest scale and longest operational period (more than 15 years) in Sichuan Province as the object and tried to analyze its practical operational performance.

Moreover, the CRI system research was mostly about the design parameters and the improvement of the technology [14-16], while the amount of research on micro-organisms has been inadequate and the research methods were traditional. Luo et al. [17] studied the growth and distribution of each micro-organism zone in the CRI system at different temperatures, but the traditional cultivation method could only examine culturable micro-organisms whose number was less than $10 \%$ of the total number of micro-organisms [18]. Therefore, this method cannot reflect the primitive existence state of the microorganism group; Xin et al. [19] utilized PCR-DGGE technology to research the space distribution regularity of ammonia-oxidizing bacteria, and although the technology overcame the disadvantages of traditional pure cultivation method of extracting total DNA of the analytical sample, it was not very feasible for accurate quantitative research. Compared with the test methods for traditional micro-organism community structure research, the metagenome analysis method based on high-throughput sequencing has the advantage of high sequencing throughput, high accuracy and excellent cost performance [20]. However, the reports about utilizing high throughput sequencing to research micro-organisms at different heights of the CRI system and to research community structures have rarely been seen.

The aim of this study was to investigate the performance of $\mathrm{COD}, \mathrm{NH}_{4}^{+}-\mathrm{N}, \mathrm{TN}$ and $\mathrm{TP}$ removal in the CRI system, which has been operated successfully for 15 years and was a demonstration project in Chengdu City of China, and reveal bacterial microbial community diversity and structure of this system at different depths. To our knowledge, this is the first study to present a variation in bacterial communities using high-throughput sequencing in CRI. CRI's performance of pollutant removal and spatial bacterial communities were an attempt to reveal the microbial mechanism and provide a theoretical basis for the long-term operation of the CRI system.

\section{Experimental}

\section{CRI System Introduction}

Phoenix River Ergou Branch Wastewater Treatment Plant (WWTP) is located at the end of the Phoenix River Ergou Branch, and it has been in operation since 2004. The main roles of the WWTP were treating rural domestic sewage, rural irrigation sewage and initial rainwater in the suburban area upriver of the Phoenix.

The project utilized the mode of the pretreatment system + CRI system + constructed wetland technology, and the designed treatment capacity was $20,000 \mathrm{~m}^{3} \mathrm{~d}^{-1}$. The CRI system was the main part of the project, and its designed hydraulic load was $1.5 \mathrm{~m}^{3} / \mathrm{m}^{2} \cdot \mathrm{d}$. There were 9 CRI tanks in the system. Fluvial shock sand, together with $5 \%$ of marble sand as infiltration media, was filled in each CRI tank, and the thickness was $120 \mathrm{~cm}$. Meanwhile, the dry-wet alternative operation plan was utilized. Water was distributed 4 times each day, and batch was operated every 7 hours. Water distribution took $1.5 \mathrm{~h}$ each time, and drying took $4.5 \mathrm{~h}$. When the sewage water flew through the filler, wastewater was delivered. Physical, chemical and biological reactions were generated to remove the pollutants. The site of the CRI system is shown in Fig. 1. 
Process flow diagram of CRI system
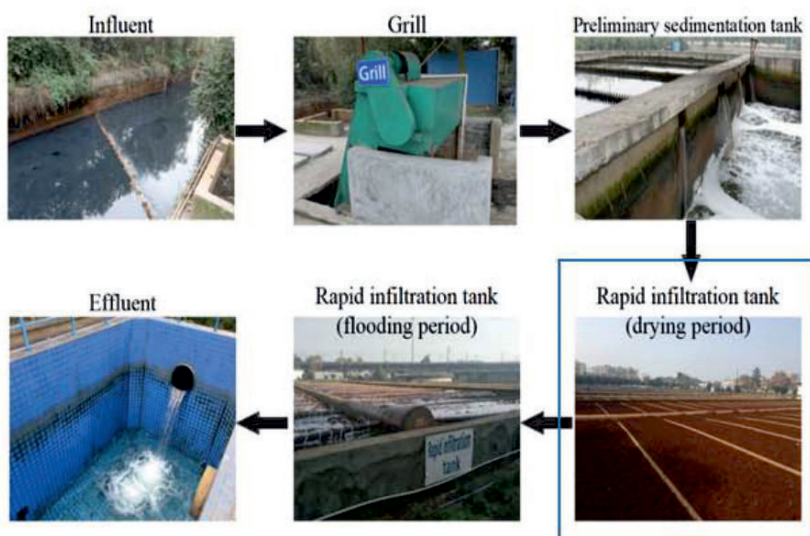

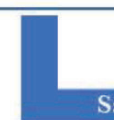

and sampling method

Fig. 1. Demonstration project of the Phoniex River CRI system in Chengdu, China; sand sampling locations and instructions for sampling number.

\section{Sampling Method}

\section{Water Sampling Method}

To study the pollutant removal performance of the CRI system, the influent quality and effluent quality of the CRI tank were monitored. The sampling time is from November 2017 to December 2017. During this period, the temperature changes greatly, from 0 to $22^{\circ} \mathrm{C}$, and the rainfall changes greatly. The average rainfall in November is $12.2 \mathrm{~mm}$, and the average rainfall in December is $4.7 \mathrm{~mm}$. Sampling frequency was once a week. When the sampling began, the water sample to be collected was used to wash the sampling apparatus and polyethylene sampling apparatus three times each. Then the samples were filled in the sampling apparatus, and the sampling apparatus was placed in the cryogenic sampling box. Next, the water sample was kept in the refrigerator in the laboratory in order to measure the concentrations of COD, $\mathrm{NH}_{4}^{+}{ }^{+} \mathrm{N}, \mathrm{TN}$ and TP.

\section{Soil Sampling Method}

To study the diversity variation regularity of the microorganisms in the CRI system in the whole process, and also to study the sampling feasibility and representativeness, this research utilized the quincunx method. One sampling point was set at the periphery and the center of the rapid infiltration tank. Vertical stratified sampling (the depth of the measurement was $120 \mathrm{~cm}$; sampling was operated every $30 \mathrm{~cm}$, and sample for five times in total) was carried out for each point from surface layer to bottom layer; then the sand samples (sand sampling locations and instructions for sampling number, shown in Fig. 1) of each sampling point were mixed evenly. After the sampling, the samples were sealed in the polyethylene sterile valve bag. Then we carried the valve bag with dry ice to the laboratory for DNA extraction and high-throughput sequencing experiment. Four parallels were carried out for all the samples. The sampling time was in December 2017.

\section{Water Quality Analysis Method}

CRI performance was monitored every week by measuring the concentrations of $\mathrm{COD}, \mathrm{NH}_{4}^{+}-\mathrm{N}, \mathrm{TN}$ and TP in the influent and effluent, which were determined according to standard methods (APHA 2005) [21]. Before the chemical analysis, the samples were filtered through $0.45 \mu \mathrm{m}$ filters, and each sample was conducted in quadruplicate.

\section{Microorganism Analysis Method}

(1) DNA extraction and quality control

The total DNA of samples were extracted at different depths in the CRI system with a Fast DNA SPIN kit for Soil (Mpbio, USA), and the operation followed the instructions. Then, Nanodrop one (Thermo Fisher Scientific, USA) was utilized to detect the concentration and total volume of DNA. A DYY-6C electrophoresis apparatus (Beijing Liuyi Biotechnology Co., Ltd.) was utilized for sepharose gio-gel PCR electrophoretic preamplification, and the completeness of the DNA samples was observed on the gel imaging system. In this way the qualification of the sample was detected.

(2) High-throughput sequencing

The extracted genome DNA was utilized to preamplify $16 \mathrm{~S}$ rRNA V3 and V4 zones. The 20 DNA stock solution extracted from 20 sand bed samples were used as the PCR template, which was preamplified by $16 \mathrm{~S}$ rDNA universal primer. The sequence of the universal primer was F: 341F: 


\section{(5'-CCTAYGGGRBGCASCAG-3'),}

$\mathrm{R}: 806 \mathrm{R}\left(5^{\prime}-\right.$ GGACTACHVGGGTWTCTAAT-3'). The reaction condition of PCR included 2 min of predegeneration at $95^{\circ}, 20 \mathrm{~s}$ of denaturation at $95^{\circ}, 30 \mathrm{~s}$ of annealing at $55^{\circ}, 30 \mathrm{~s}$ of extension at $72^{\circ}, 30$ circulations, 5 min of heat preservation at $72^{\circ}$ and preservation at $4^{\circ}$. Quality testing was carried out for the amplified product with $1 \%$ agarose gel electrophoresis. Next, bead depuration and library construction were carried out. The constructed library was quantified with Qubit and QPCR. Computer sequencing was implemented after the library was qualified.

After the logging out of sequencing data, the quality of the sequencing data were filtered, spliced and controlled. The concrete flows include: (1) removing the barode and primer sequences at the two ends of reads; (2) spliced overlap of Read 1 and Read 2 with FLASH software, and the spliced sequence is Raw Tags. The requirement of the splicing process is that the minimum length in the overlap zone is $10 \mathrm{bp}$, and the maximum mispairing rate is $10 \%$; (3) carried out quality control for Raw Tags with Qiime, cut off Tags with more than 5 continuous $\mathrm{N}$ or low-quality base group, and then filter out the Tags whose continuous high-quality base group length is less than $75 \%$ of the Tag length, and then Clean Tags was gained; (4) removing the chimera in the Clean Tags. Chimera refers to the wrong sequence generated in the process of PCR amplification. UCHIME algorithm was utilized to verify the chimera.
Compared with the Gold database, Effective Tags for subsequent data analysis were gained after the removal of the chimera sequence. USEARCH method was utilized to aggregate the Effective Tags of each sample and aggregate the sequences whose sequence similarity reaches $97 \%$ in one OTU.

\section{Results and Discussion}

\section{CRI Performance}

\section{Organic Matter Removal Performance of the CRI}

The removal process of organic matter by CRI mainly involved filtration interception, filler absorption, biodegradation, etc. [22-23]. The removal effect of CRI on COD was shown in Fig. 2a), which shows that the fluctuation of influent concentration was great, ranging from $91.60 \mathrm{mg} \mathrm{L}^{-1}$ to $200.80 \mathrm{mg} \mathrm{L}^{-1}$. The main influence factors were pollution source, initial rain, temperature, etc. The effluent concentration of COD was $26.20-42.80 \mathrm{mg} \mathrm{L}^{-1}$, and the average removal efficiency was $75.52 \%$. All the effluent concentration can reach the A standard of COD $\left(<50 \mathrm{mg} \mathrm{L}^{-1}, \mathrm{~GB}\right.$ 18918-2002, China), which showed that the CRI system had strong removal effect for organic matter, strong impulsion load resistance, and stable operation. Chen et a)

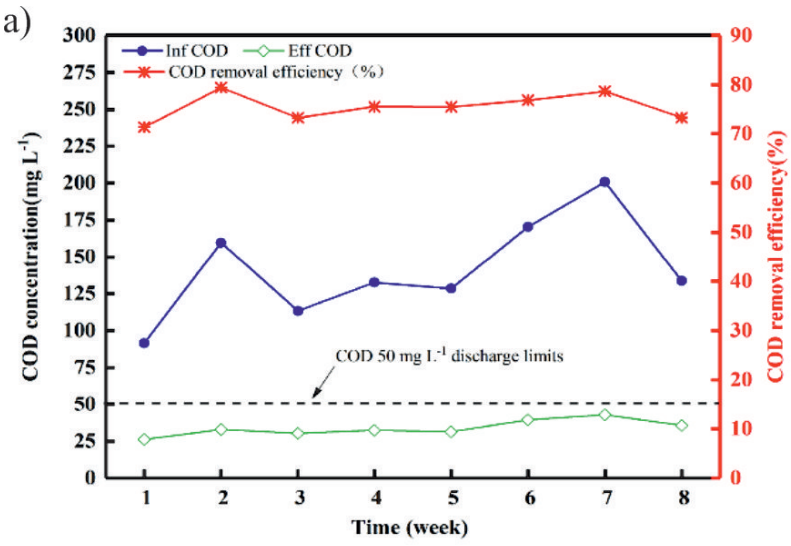

c)

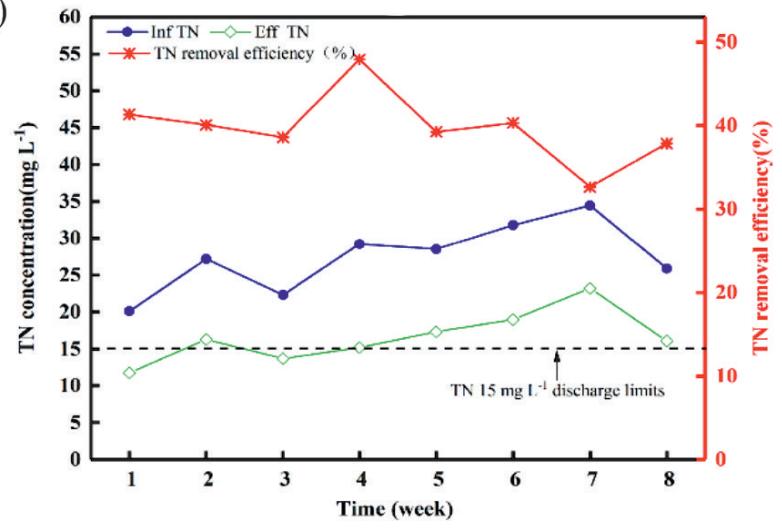

b)

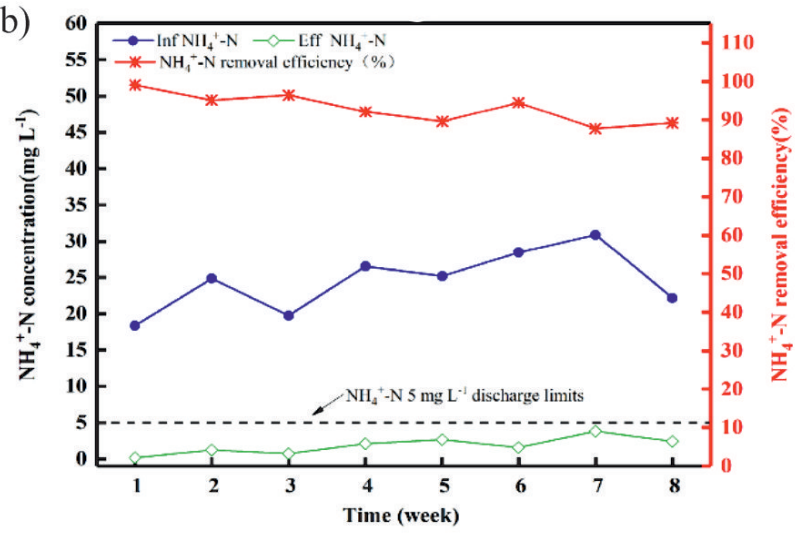

d)

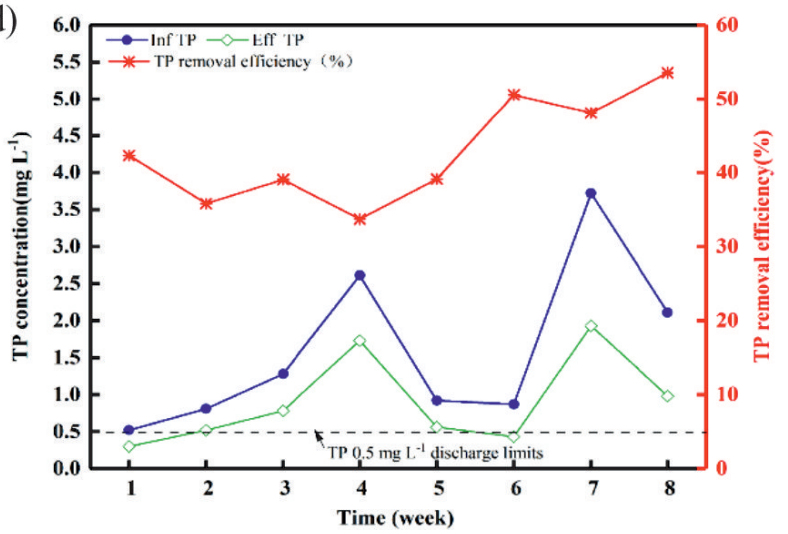

Fig. 2. Removal performance of the CRI system: a) $\mathrm{COD}$, b) $\mathrm{NH}_{4}^{+}-\mathrm{N}$, c) TN, d) TP. 
al. [6] investigated the removal performance in winter for a certain CRI system of Chongqing City, and found that during the whole winter, the average removal efficiency of the technology for COD was $68.58 \%$, while the average removal rate for COD by this system was $75.52 \%$, which showed that this system was better than the CRI system project.

\section{Nitrogen Removal Performance of the CRI}

The removal of nitrogen-type pollutants mainly involved absorption for filter materials, degradation and assimilation of micro-organisms, with microorganisms playing the main role [24]. The removal effect by the rapid infiltration tank of the CRI system on $\mathrm{NH}_{4}^{+}-\mathrm{N}$ is shown in Fig. 2b). The influent concentration of $\mathrm{NH}_{4}^{+}-\mathrm{N}$ was 18.35-30.90 $\mathrm{mg} \mathrm{L}^{-1}$, and the effluent concentration of $\mathrm{NH}_{4}^{+}-\mathrm{N}$ was $0.16-3.81 \mathrm{mg} \mathrm{L}^{-1}$. The average removal efficiency was $92.94 \%$, which indicated that the removal performance of this CRI system for $\mathrm{NH}_{4}^{+}-\mathrm{N}$ was strong. The effluent concentration of $\mathrm{NH}_{4}^{+}-\mathrm{N}$ could reach the A standard of $\mathrm{NH}_{4}^{+}-\mathrm{N}\left(<5 \mathrm{mg} \mathrm{L}^{-1}\right.$, GB 18918-2002, China). However, the average removal efficiency of TN was $39.74 \%$, so the effluent concentration can seldom reach A standard of $\mathrm{TN}$ ( $<15 \mathrm{mg} \mathrm{L}^{-1}$, GB 18918-2002, China). Liu et al. [25] and $\mathrm{Xu}$ et al. [14] both got the conclusion that the CRI system had strong removal effect for $\mathrm{NH}_{4}^{+}-\mathrm{N}$ but weak removal effect for $\mathrm{TN}$. The main possible reason was that the inadequacy of carbon source in the denitrification section in the sublayer of the CRI system led to the weak role of denitrification effect [26], and also the transference speed of nitrate nitrogen was too fast so the time of denitrification reaction period was too short [27]. Fang et al. [28] pointed out that TN removal efficiency can be improved to $75.4 \%$ after adding a postpositional waterlogged layer to coordinate the carbon nitrogen ratio.

\section{Phosphorous Removal Performance of the CRI}

Three methods remove phosphorus from CRI system: absorption, chemical precipitation and absorption of micro-organisms [5]. Different from the removal mechanisms of $\mathrm{COD}, \mathrm{NH}_{4}^{+}-\mathrm{N}$ and $\mathrm{TN}$, the contribution of biological effect on phosphorus removal was limited. The absorption and precipitation of substrates were the main ways to remove phosphorus, of which the precipitation role refers to the common precipitation roles of $\mathrm{Fe}^{3+}, \mathrm{Al}^{3+}$, other metal ions and phosphate anion, which is shown in Formulas (1) and (2) [29]:

$$
\begin{gathered}
\mathrm{Fe}^{3+}+\mathrm{H}_{n} \mathrm{PO}_{4}^{-3+n} \rightarrow \mathrm{FePO}_{4} \downarrow+n \mathrm{H}^{+} \\
\mathrm{Al}^{3+}+\mathrm{H}_{n} \mathrm{PO}_{4}^{-3+n} \rightarrow \mathrm{AlPO}_{4} \downarrow+n \mathrm{H}^{+}
\end{gathered}
$$

The removal effect of TP by the rapid infiltration tank of the CRI system is shown in Fig. 2d), where the influent concentration of TP was $0.52-3.72 \mathrm{mg} \mathrm{L}^{-1}$ and the effluent concentration of TP was $0.30-1.23 \mathrm{mg} \mathrm{L}^{-1}$. The average removal efficiency was only $42.78 \%$. Only few effluent concentrations can reach A standard of TP $\left(<0.5 \mathrm{mg} \mathrm{L}^{-1}\right.$, GB 18918-2002, China, which showed that the CRI system had weak removal performance). Wang [30] found that a mixture of iron scrap and fly-ash can effectively remove phosphorus-containing pollutants as a phosphorus removal filler with mass ratio of $2: 1 \mathrm{Xu}$ et al. [31] pointed out that utilizing sponge iron as filler can improve the removal efficiency of TP to $72.5 \%$. In conclusion, changing the filler ingredients in the rapid infiltration tank can improve TP removal efficiency. In addition, the conversion and decomposition of microorganisms on phosphorus exerted certain effects due to seasonally low temperatures.

\section{Microbial Community Diversity Analysis of the CRI at Different Depths}

\section{OTU Analysis}

To study the genus composition and diversity information of the samples, the USEARCH method was adopted to aggregate the Effective Tags of each sample. The sequences where sequence similarity reached $97 \%$ were aggregated into an OTU. Statistical analysis was carried out for the OTU generated by the 5 groups of samples (see Fig. 3), and the result showed that all the samples formed 306,222 OTU, wherein the number of samples in group 1 (surface layer) was 58,918, the number of samples in group 2 (at a depth of $30 \mathrm{~cm}$ ) was 73,963 , the number of samples in group 3 (at a depth of $60 \mathrm{~cm}$ ) was 53,099, the number of samples in group 4 (at a depth of $90 \mathrm{~cm}$ ) was 65,033 and the number of samples in group 5 (at a depth of $120 \mathrm{~cm}$ ) was 55,209. As the depth of the CRI system increases, the number of OTU increased at first, decreased later, then increased again and decreased again. The number reached the

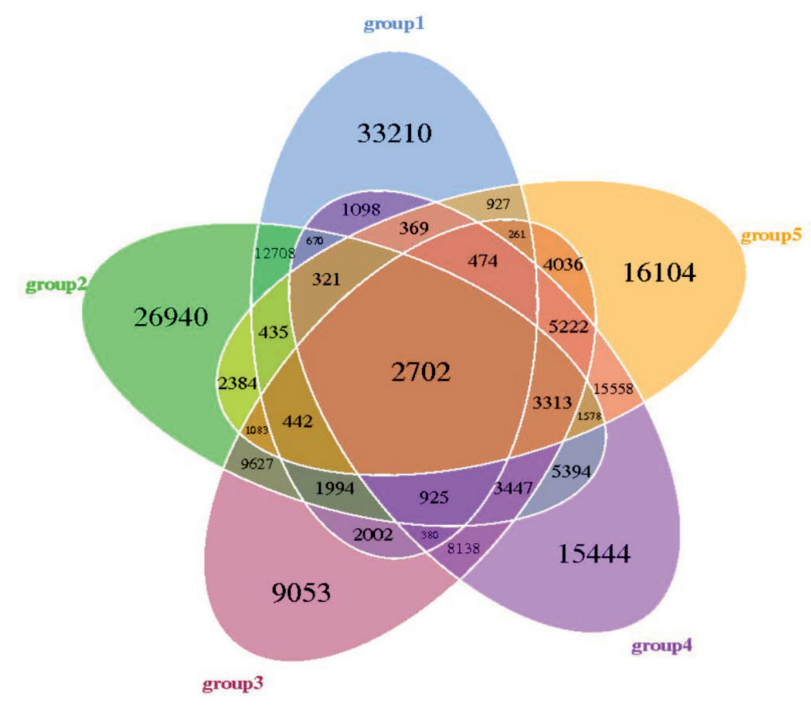

Fig. 3. Venn diagram showing distribution of OTUs. 
maximum value when the depth was $30 \mathrm{~cm}$. When the depth was $60 \mathrm{~cm}$, the number of OTU was 53,099, which showed that the number of microorganism genus at this depth was the smallest. There were 2,702 OTU in the 5 groups of samples, which indicated that the 2702 OTU had displayed and included all the dominant bacterial communities in the CRI system. However, the number of common OTU in the 5 groups of samples only accounted for $0.88 \%$ of the total number, which indicated that the microorganism communities at different depths not only differed in number, but also in genus. That was caused by different physicochemical characteristics of the filtration tank at different depths, such as dissolved oxygen, pollutant concentration, and hydraulic condition, so the properties of the microorganisms at different depths of the filtration tank were different.

\section{Richness and Richness of the Bacterial Community}

The diversity of the bacterial communities for the CRI samples at different depths are described in Table 1.

Table 1 shows that the Chaol index indicated genus diversity, and its value was between $42,589.53$ and 70,697.93. Simpson index indicated the genus uniformity whose value was between 0.997 and 0.999. Shannon index was an aggregative index of genus richness and uniformity, and its value was between 11.57 and 12.35. The larger these indexes, the more diverse the genus of the samples. The Shannon and Chaol indices indicated that the microorganism community richness and diversity on the sublayer $(60-120 \mathrm{~cm})$ of the CRI tank were small, and the reason was that the amount of DO and nutrient substances in the sublayer of the CRI tank was small, so the genus diversity in the sublayer was weak. The values of Simpson indexes were all close to 1 , which indicated that the microorganism communities at different depths of the CRI tank had high uniformity. In addition, the Simpson index on the upper layer (0-30 $\mathrm{cm})$ was higher than the Simpson index on the sublayer $(60-120 \mathrm{~cm})$. The Shannon and Chaol indices also took on this trend, which implies that the community structure of the microorganisms on the upper layer was more stable. Chen et al. [32] held that the more diverse the bacterial community structure, the better the removal efficiency of pollutants.

\section{Microbial Community Structure Analysis of the CRI at Different Depths}

\section{Bacterial Community Composition at the Phylum Level}

The 5 groups of CRI bacterial community structures at different depths took on high degrees of diversities at the phylum level. There were 52, 85, 51, 75 and 46 known bacterial phyla detected respectively in groups 1, 2, 3, 4 and 5. The relative proportions of bacterial phyla with comparatively higher community composition percentage (the first 10) in the 5 groups of samples are shown in Fig. 4, and the bacterial phyla mainly included Proteobacteria (24.26-29.20\%), Actinobacteria (2.02-21.77\%), Chloroflexi (12.14$16.66 \%)$, Acidobacteria (7.77-14.73\%), Thaumarchaeota (1.23-10.86\%), Bacteroidetes $\quad(0.99-8.66 \%)$, Nitrospirae (2.85-8.18\%), Firmicutes (0.95-5.96\%), Gemmatimonadetes (1.83-5.25\%), and Saccharibacteria (0.46-3.12\%).

Among the dominant bacteria phyla, Proteobacteria and Chloroflexi took up comparatively higher proportions in each sample, at respectively $24.26-29.20 \%$ and $12.14-16.66 \%$. Proteobacteria and Chloroflexi were detected as the main dominant phyla with a high frequency for wastewater treatment [3334]. Proteobacteria could be related to the removal of various organic matters from wastewater [35]. Meanwhile, Proteobacteria has the function of nitrogen and phosphorus removal, such as Nitrosomonas and Nitrosococcus genus in AOB, and Nitrobacter and Nitrococcu in NOB all belong to Proteobacteria phyla [36-37]. Chloroflexi is mainly detected in the sewage plant with complex treatment ingredients and large variation of water quality [38], which was consistent with the conclusion of the experiment.

According to the abundance of phyla, the abundances of Actinobacteria and Bacteroidetes in group 1 (respectively $21.77 \%$ and $8.66 \%$ ) were much higher than those in groups 2-5 (respectively 3.5-6.22\% and $0.99-1.75 \%$ ). Namely, the surface layer contained more Actinobacteria and Bacteroidetes. Actinobacteria [35] and Bacteroidetes [39] mainly existed in the place where the organism is concentrated. The influent of the CRI was from the upper part uniformly, so the organism concentration on the surface was the highest,

Table 1. Spatial richness and diversity of bacterial community for sand samples collected from different depths in the CRI system.

\begin{tabular}{|c|c|c|c|c|c|}
\hline Sample & Sampling number & OTU & Chao1 & Shannon & Simpson \\
\hline $0 \mathrm{~cm}$ & group 1 & 58918 & 53930.11 & 12.16 & 0.999 \\
\hline $30 \mathrm{~cm}$ & group 2 & 73963 & 70697.93 & 12.35 & 0.999 \\
\hline $60 \mathrm{~cm}$ & group 3 & 53099 & 48313.76 & 11.65 & 0.998 \\
\hline $90 \mathrm{~cm}$ & group 4 & 65033 & 52596.90 & 11.67 & 0.997 \\
\hline $120 \mathrm{~cm}$ & group 5 & 55209 & 42589.53 & 11.57 & 0.998 \\
\hline
\end{tabular}




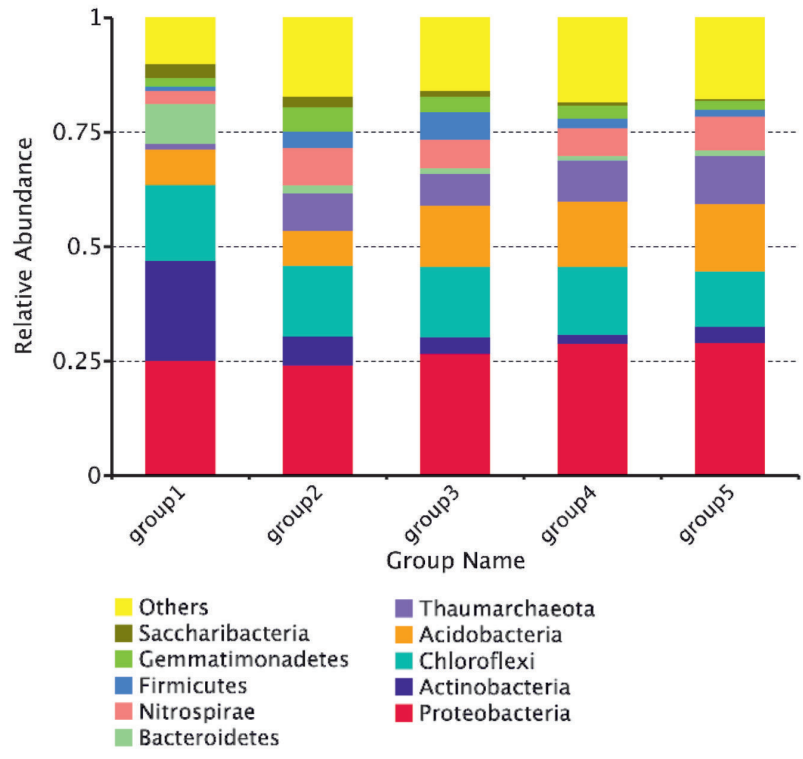

Fig. 4. Relative abundance (\%) of dominant microbial phyla in all sand samples at different depths; bacterial community structure and distribution of the samples at phylum level.

which caused the abundances of Actinobacteria and Bacteroidetes to be higher. Meanwhile, it was predicted that organism degradation existed on the system surface, while the abundances of Firmicutes and Nitrospirae in group 1 (respectively 0.95 and $2.85 \%$ ) were less than those in groups $2-5$ (respectively $1.5-3.64 \%$ and $6.11-8.18 \%$ ). That is to say the inside $(30-120 \mathrm{~cm})$ of CRI had more Firmicutes and Nitrospirae, which is a kind of microorganism flora for nitrogen removal. For example, Nitrospira in NOB belonged to Nitrospirae phylum; the Firmicutes bacteria had to be denitrified with nitrate [40-41]. Meanwhile, the bacillus in Phylum Firmicutes had a strong capacity for resisting exterior harmful factors [40-41], so it played a key role in the removal of nitrogen in wastewater and the maintenance of system stability. According to the distribution of Actinobacteria, Bacteroidetes, Firmicutes and Nitrospira, it can be predicted that the degradation of organisms in CRI mainly existed in the system surface, while the nitration reaction mainly happened in the inside of the system.

For a long time, researchers believed that ammoniaoxidizing bacteria were the most important carriers in the nitrogen circulation of the earth. However, since 2005 the first ammonia-oxidizing archaea (AOA) gained by separate cultivation in the seawater of Seattle Aquarium proved that archaea can also oxidize ammonia to nitrite, which broke through the cognition to nitrogen circulation. It is worth noticing that archaea Thaumarchaeota, which is initially classified as mesophilic Crenarchaeota [43], was detected in this experiment. Known from Fig. 5, the abundance values of groups $1-5$ were respectively $1.23 \%, 8.16 \%$, $7 \%, 8.92 \%$ and $10.36 \%$. The abundance value on the sublayer of the CRI was higher, which was consistent

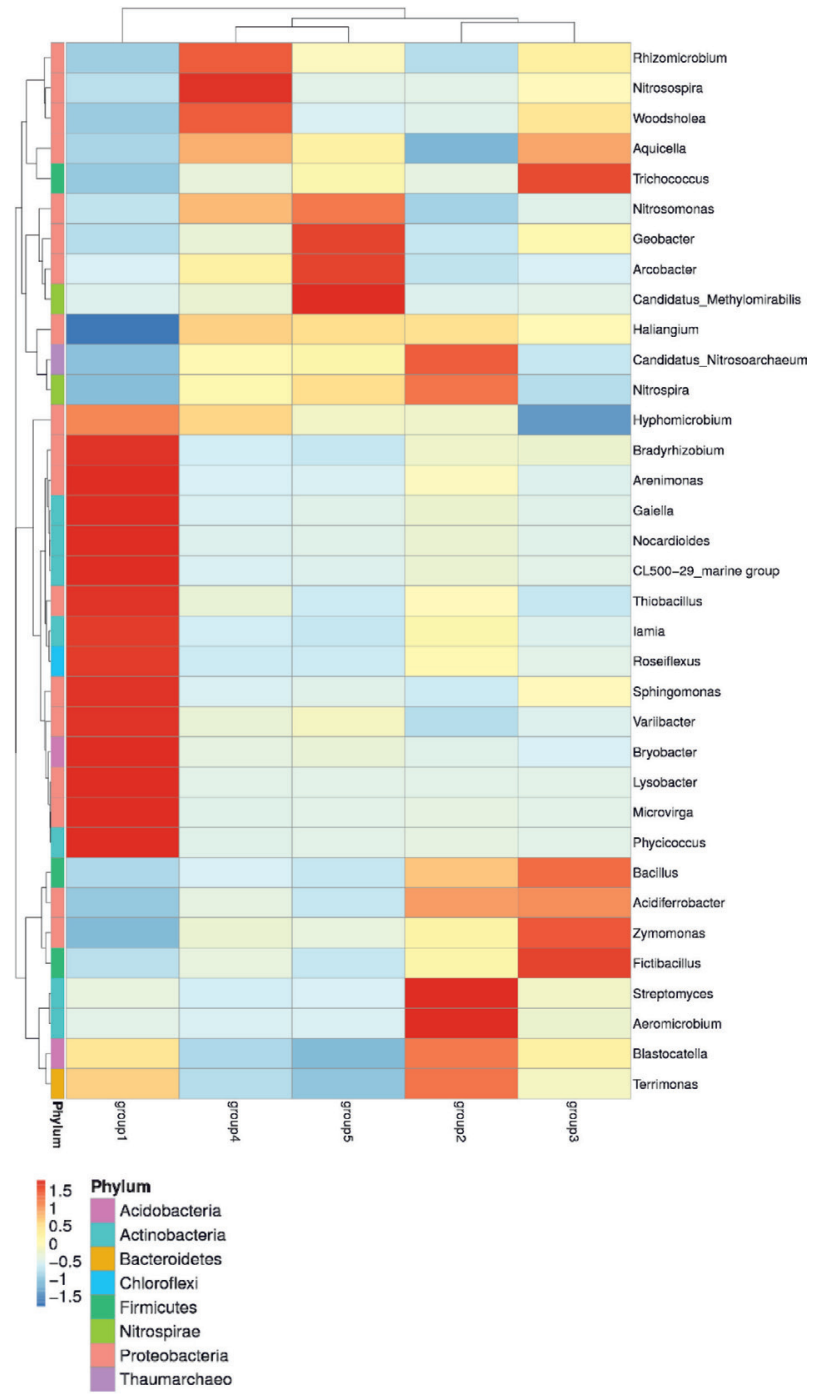

Fig. 5. Heat map of most abundant genera in bacterial communities detected from CRI samples at different depths.

with archaea's endurance of oxygen deficiency and the low concentration of $\mathrm{NH}_{4}^{+}-\mathrm{N}$. Research [44] indicated that Thaumarchaeota was richer than bacteria in some sand and silty clays, which was consistent with our study.

\section{Bacterial Community Composition at the Genus Level}

To get the CRI microbial community structure difference at different depths, this study was based on the genus annotation and richness information of the genus level in groups $1-5$, the genus whose richness ranks were in the first 35 were drawn into heatmap, as shown in Fig. 5. The result showed that the microbial community structure varied as the change of depth. The clustering analysis on the abundance of genusgrade microorganisms showed the difference between the microbial community structure on the surface layer (group 1) of CRI and the microbial community structure in the inside (group 2-5) of CRI was large, 
but the middle and upper layers (group 2) in the inside of CRI shared similarities with the middle layer (group 3), middle and lower layers (group 4) and bottom layer (group 5) in the microbial community structure. Meanwhile, the similarities of microbial community structures between the upper layer, middle layer and the similarities in the middle lower layer and bottom layer were larger than the similarities between the upper layer, middle layer and the surface layer. In addition, principal co-ordinates analysis ( $\mathrm{PCoA})$ was made for all the samples based on weighted unifrac distance and unweighted unifrac distance. As shown in Fig. 6, the result was consistent with the aggregation analysis of genus-grade microorganism abundance caused by the difference and similarities in the micro-environment (substrate concentration, oxygen, $\mathrm{pH}$ and $\mathrm{Eh}$ ).

The great difference between the community structures of group 1 and groups 2-5 was mainly due to the big gap in dominant genus. In group 1, the abundance degree of Bradyrhizobium, Arenimonas, Gaiella, Nocardioides, CL500-29_marine group, Thiobacillus, Iamia, Roseiflexus, Sphingomonas, Variibacter, Bryobacter, Lysobacter, Microvirga, and Phycicoccu were high, ranging from $0.43 \%$ to $1.62 \%$, while the bacteria abundance in group 2-5 were low, ranging from $0 \%$ to $0.2 \%$, wherein Bradyrhizobium, Variibacter and Microvirga had the role of nitrogen fixation [45]. Thus, in the process of sampling, it was found that the surface layer of CRI had a small amount of weed, which was due to the long-time operation of this system in which the influent nitrogen concentration is high. Furthermore, most of these bacteria had the capacities of utilizing carbon source and decomposing organic matter. For example, Bryobacter was frequently detected in cultivated soil, and it can decompose organic matter [46]. Meanwhile, the abundance of Bryobacter is

PCoA - PC1 vs PC2

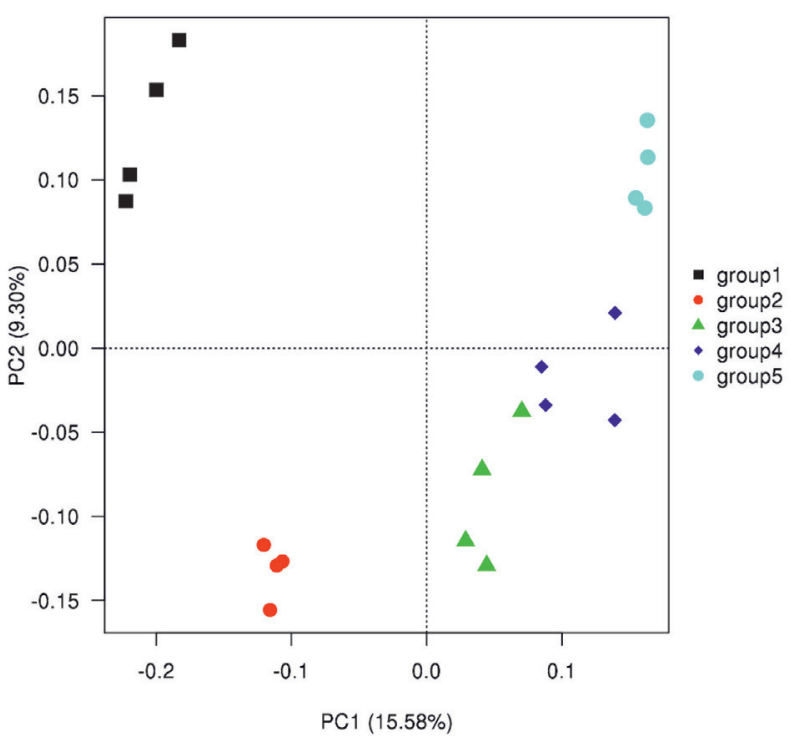

Fig. 6. PCoA plot on the OTU level. positively correlated to TP [46]. Arenimonas [48], Iamia [49] and Roseiflexus [50] were frequently detected in activated sludge belonging to heterotrophic bacterium; Thiobacillus was both heterotrophy nitrate-reducing bacteria and also autotrophic sulfide-oxidizing [51]. Zhang et al. [52] found the predominance of Thiobacillus in different sulfur-based denitrification systems after treating nitrate-contaminated wastewater, and its existence was related to the sulfur cycle. Furthermore, in the dominant genus of group 1, some bacteria had the functions of transforming heavy metal and degrading toxic and harmful substances. The research showed that Nocardioides could not only decompose cellulose, lignin, polycyclic aromatic hydrocarbon and related molecular organic components, but also could degrade toxic compounds such as fungicide, herbicide and insecticide, and can degrade petroleum hydrocarbon compound [53-54]. Sphingomonas had the biodegradation capacity of an aromatic compound, but as the knowledge of Sphingomonas was gained relatively later, its ecological and economic value potential were great [55]. Phycicoccus can degrade xenobiotics, degrade ritalinic acid and related substances [56]. Gaiella had some relation with the transformation of heavy metal. Liu et al. [57] discovered that the abundance degree of Gaiella in nonferrous metal (loid) tailings sites was high.

In the system, the transformation of oxynitride was mainly concentrated in groups 2-5. The nitrogen transformation functional bacteria ranking in the TOP35 of heatmap were selected and classified into 5 types (see Table 2) according to the transformation regularity of oxynitride: the first was $\mathrm{AOB}$, which oxidized $\mathrm{NH}_{4}^{+}-\mathrm{N}$ into $\mathrm{NO}_{2}^{-}-\mathrm{N}$; the second was $\mathrm{NOB}$, which oxidized $\mathrm{NO}_{2}^{-}$ $-\mathrm{N}$ into $\mathrm{NO}_{3}^{-}-\mathrm{N}$; the third was AOA, which oxidized $\mathrm{NH}_{4}^{+}-\mathrm{N}$ into $\mathrm{NO}_{2}^{-}-\mathrm{N}$; the fourth was denitrifying bacteria, which reduced $\mathrm{NO}_{3}^{-}-\mathrm{N}$ into $\mathrm{N}_{2}$; and the fifth was novel bacteria - N-DAMO and ANAMMOX. Nitrite-dependent anaerobic methane oxidation (N-DAMO) was a novel nitrogen removal method, coupling the reduction of nitrite and the anaerobic oxidation of methane of methane, and the reaction formula was shown in formula (3) [58]. Furthermore, research indicated that the N-DAMO microorganism usually coexisted with anaerobic ammonia-oxidizing microorganisms [59], so ANAMMOX bacteria were found at the depth of 90-120 cm. Meanwhile, it was positively correlated to abundance degree of N-DAMO bacteria. The equation of ANAMMOX was shown in Equation (4) [60]:

$$
\begin{gathered}
3 \mathrm{CH}_{4}+8 \mathrm{NO}_{2}^{-}+8 \mathrm{H}^{+} \rightarrow 3 \mathrm{CO}_{2}+4 \mathrm{~N}_{2}+10 \mathrm{H}_{2} \mathrm{O}_{(3)} \\
\mathrm{NH}_{4}^{+}+1.32 \mathrm{NO}_{2}^{-}+0.066 \mathrm{HCO}_{3}^{-}+0.13 \mathrm{H}^{+} \rightarrow \\
1.02 \mathrm{~N}_{2}+0.256 \mathrm{~N}_{2}+0.066 \mathrm{CH}_{2} \mathrm{O}_{0.5} \mathrm{~N}_{0.15}+2.03 \mathrm{H}_{2} \mathrm{O}_{(4)}
\end{gathered}
$$

Table 2 shows that the abundance of nitrobacteria in groups 1-5 was high, wherein the abundance of Nitrospira was the highest. Even on the CRI bottom 
Table 2. Characteristics of nitrogen transformation functional bacteria in the CRI system samples.

\begin{tabular}{|c|c|c|c|c|c|c|c|}
\hline \multirow{2}{*}{\multicolumn{2}{|c|}{ Functional bacteria }} & \multirow{3}{*}{$\begin{array}{c}\text { Genus } \\
\text { Nitrosospira }\end{array}$} & \multicolumn{5}{|c|}{ Relative Abundance (\%) } \\
\hline & & & \multirow{2}{*}{$\frac{\text { group 1 }}{0.03 \%}$} & \multirow{2}{*}{$\begin{array}{c}\text { group } 2 \\
0.11 \%\end{array}$} & \multirow{2}{*}{$\frac{\text { group } 3}{0.20 \%}$} & \multirow{2}{*}{$\begin{array}{c}\text { group } 4 \\
0.62 \%\end{array}$} & \multirow{2}{*}{$\frac{\text { group } 5}{0.11 \%}$} \\
\hline \multirow{4}{*}{$\begin{array}{c}\text { Nitrifying } \\
\text { bacteria }\end{array}$} & \multirow{2}{*}{$\mathrm{AOB}$} & & & & & & \\
\hline & & Nitrosomonas & $0.07 \%$ & $0.04 \%$ & $0.11 \%$ & $0.34 \%$ & $0.43 \%$ \\
\hline & \multirow{2}{*}{ NOB } & Rhizomicrobium & $0.01 \%$ & $0.11 \%$ & $0.96 \%$ & $1.88 \%$ & $0.67 \%$ \\
\hline & & Nitrospira & $2.36 \%$ & $5.58 \%$ & $2.81 \%$ & $3.95 \%$ & $4.55 \%$ \\
\hline Archaea & $\mathrm{AOA}$ & Candidatus Nitrosoarchaeum & $0.01 \%$ & $2.83 \%$ & $0.43 \%$ & $1.25 \%$ & $1.39 \%$ \\
\hline \multirow{4}{*}{\multicolumn{2}{|c|}{ Denitrifying bacteria }} & Arcobacter & $0.29 \%$ & $0.21 \%$ & $0.28 \%$ & $0.68 \%$ & $1.33 \%$ \\
\hline & & Haliangium & $0.18 \%$ & $0.46 \%$ & $0.39 \%$ & $0.48 \%$ & $0.47 \%$ \\
\hline & & Bacillus & $0.18 \%$ & $0.89 \%$ & $1.21 \%$ & $0.29 \%$ & $0.25 \%$ \\
\hline & & Acidiferrobacter & $0.04 \%$ & $1.31 \%$ & $1.36 \%$ & $0.40 \%$ & $0.22 \%$ \\
\hline \multirow{2}{*}{ Novel bacteria } & N-DAMO & Candidatus Methylomirabilis & $0.00 \%$ & $0.00 \%$ & $0.02 \%$ & $0.07 \%$ & $0.63 \%$ \\
\hline & Anammox & Candidatus Brocadia & $0.00 \%$ & $0.00 \%$ & $0.01 \%$ & $0.03 \%$ & $0.09 \%$ \\
\hline
\end{tabular}

layer $(120 \mathrm{~cm})$ which was poor in nutrient substance and low in oxygen amount, the abundance was as high as $4.55 \%$, which was because when the $\mathrm{NO}_{2}^{-}-\mathrm{N}$ was adequate, Nitrospira preferred the low dissolved oxygen environment [61]. What is interesting is that we found that the abundance of archaea Candidatus Nitrosoarchaeum was larger than that of AOB in the inside (groups 2-5) of CRI, ranging from 0.43-2.83\%. The synergistic effect of nitrobacteria and archaea improved the removal efficiency of $\mathrm{NH}_{4}^{+}-\mathrm{N}$ in CRI. Known from Table 2, the summation of denitrifying bacteria Arcobacter, Haliangium, Bacillus and Acidiferrobacter was the highest in group 3, and the value was $3.24 \%$. This indicated that the denitrifying role in CRI was mainly in the middle layer of the system.

In addition, some microorganisms that can decompose molecular organic matter existed in groups 2-5, such as Woodsholea, Woodsholea, Trichococcus and Hyphomicrobium. No phosphorus-removing microorganism was found in soil remediation and in the first 35 genus, which implied that the contribution of microorganisms to phosphorus removal was limited in the CRI system.

Above all, each microorganism played its own role in CRI. Through mutual synergistic effect, the CRI system possessed strong pollutant-removal capacities.

\section{Conclusions}

1. As the influence of pollution source, initial rainwater, temperature, etc., the influent concentrations of $\mathrm{COD}, \mathrm{NH}_{4}^{+}-\mathrm{N}, \mathrm{TN}$ and $\mathrm{TP}$ were high. After CRI treatment, the effluent concentrations of COD and $\mathrm{NH}_{4}^{+}-\mathrm{N}$ can reach $\mathrm{A}$ standard $\left(\mathrm{COD}<50 \mathrm{mg} \mathrm{L}^{-1}\right.$, $\mathrm{NH}_{4}^{+}-\mathrm{N}<5 \mathrm{mg} \mathrm{L}^{-1}$ GB 18918-2002, China).
2. Microorganisms at different depths differ in species and quantity, and that is mainly due to different physicochemical properties, such dissolved oxygen, pollutant concentration, hydraulic condition, etc. The diversity indexes (Shannon, Simpson, chaol) of the microorganisms within $0-30 \mathrm{~cm}$ were all higher than those in the under layer.

3. Most of the microorganisms on the surface layer $(0 \mathrm{~cm})$ of CRI possess the capacities to degrade organic matter, and some of the microorganisms possess the capacities of degrading toxic compounds and converting heavy metal.

4. Nitrogen transformation functional bacteria were mainly distributed in $30-120 \mathrm{~cm}$. The nitrifying bacteria were mainly Nitrospira (2.81-5.58\%), and the denitrifying bacteria were mainly Acidiferrobacter (0.22-1.31\%). The archaea were mainly Candidatus Nitrosoarchaeum (0.43-2.83\%). In addition, Novel nitrogen transformation functional bacteria, N-DAMO bacteria - Candidatus Methylomirabilis (0.02-0.63\%) and Anammox bacteria - Candidatus Brocadia (0.01-0.09\%) were found within 60-120 cm.

\section{Acknowledgements}

This research was funded by the Chinese National Natural Science Foundation (41502333), the China Postdoctoral Science Foundation (2017M610598, 2018T110963), and the State Key Laboratory of Geohazard Prevention and Geoenvironment Protection Foundation (SKLGP2018Z007).

\section{Conflict of Interest}

The authors declare no conflict of interest. 


\section{References}

1. ZHANG X., DOU Y., GAO C., HE C., GAO J., ZHAO S., DENG L. Removal of Cd(II) by modified maifanite coated with Mg-layered double hydroxides in constructed rapid infiltration systems. Sci. Total Environ. 685 951, 2019.

2. ZHANG X., GUO L., HUANG H., JIANG Y., LI M., LENG Y. Removal of phosphorus by the core-shell bioceramic/Zn-layered double hydroxides (LDHs) composites for municipal wastewater treatment in constructed rapid infiltration system. Water Res. 96 280, 2016.

3. GAO C., ZHANG X., YUAN Y., LEI Y., GAO J., ZHAO S., HE C., DENG L. Removal of hexavalent chromium ions by core-shell sand/Mg-layer double hydroxides (LDHs) in constructed rapid infiltration system. Ecotox. Environ. Safe. 166 285, 2018.

4. YANG L., KONG F., XI M., LI Y., WANG S. Environmental economic value calculation and sustainability assessment for constructed rapid infiltration system based on emergy analysis. J. Clean. Prod. 167 582, 2017.

5. WANG M., ZHANG H. Experimental Research on Rural Domestic Sewage Treatment by a Strengthened Constructed Rapid Filtration System. Fresen. Environ. Bull. 26 (5), 3550, 2017.

6. CHEN Y., QIN Y., HU S., LU T., TAN Z. Diagnostic analysis of sewage treatment using constructed rapid infiltration system in winter. Chinese Journal of Environmental Engineering. 10 (09), 4927, 2016.

7. CHAO L.I., HOU C., WEIZHONG W.U. Demonstration project of constructed rapid infiltration system for water treatment of the Daqing River. Ecology \& Environmental Sciences. 19 (12), 2960, 2010.

8. WU C., LI X. Analysis of Seasonal Operation Effects of CRI and WRSIS Integrated System on Rural Domestic Sewage. Southwest China Journal of Agricultural Sciences. 31 (1), 177, 2018.

9. LI L., LI H. Application of Constructed Rapid Infiltration Process in Water Quality Improvement of Shending River. China Water \& Wastewater. 35 (2), 79, 2019.

10. GAO P., LI Y., GUO X., HUANG T., YUAN D., TAN X. Detecting the Changes of Water Qualities and Fluorescent DOM in a Constructed Rapid Infiltration System. Wetlands. 37 (3), 585, 2017.

11. SEGISMUNDO E.Q., KIM L., JEONG S., LEE B. A Laboratory Study on the Filtration and Clogging of the Sand-Bottom Ash Mixture for Stormwater Infiltration Filter Media. Water-Sui. 9 (1), 321, 2017.

12. WANG M., ZHANG H. Chemical Oxygen Demand and Ammonia Nitrogen Removal in a Non-saturated Layer of a Strengthened Constructed Rapid Infiltration System. Water Air Soil Poll. 228 (11), 440, 2017.

13. CHEN Y., QIN Y., HU S., LU T., TAN Z. Diagnostic analysis of sewage treatment using constructed rapid infiltration system in winter. Chinese Journal of Environmental Engineering. 10 (9), 4927, 2016.

14. XU W.L., ZHANG W., JIAN Y., WANG J., TANG M., PEI X.J. Analysis of Nitrogen Removal Performance of Constructed Rapid Infiltration System (CRIS). Appl. Ecol. Env. Res. 15 (1), 199, 2017.

15. CHEN J., LU Y., CHENG J., ZHANG J. Effect of starvation on the nitrification performance of constructed rapid infiltration systems. Environ. Technol. 40 (11), 1408, 2019.

16. FANG Q., XU W., YAN Z., QIAN L. Effect of Potassium Chlorate on the Treatment of Domestic Sewage by Achieving Shortcut Nitrification in a Constructed Rapid
Infiltration System. Int. J. Env. Res. Pub. He. 15 (4), 670, 2018.

17. LUO L., LIU H., LI X., WANG F. Research on the growth and distribution of microorganism in constructed rapid infiltration system system. Environmental Pollution \& Control. 34 (11), 59, 2012.

18. SWEDRZYNSKA D., GRZES S. Microbiological Parameters of Soil under Sugar Beet as a Response to the Long-Term Application of Different Tillage Systems. Pol. J. Environ. Stud. 24 (1), 285, 2015.

19. JIANG X., MA M., LI J., LU A., ZHONG Z. Analysis of microbial molecular ecology techniques in constructed Rapid Infiltration system. J. Earth Sci-China. 22 (5), 669, 2011.

20. SELVARAJAN R., SIBANDA T., SEKAR S., NEL W.A.J. Industrial Effluents Harbor a Unique Diversity of Fungal Community Structures as Revealed by High-throughput Sequencing Analysis. Pol. J. Environ. Stud. 28 (4), 2353, 2019.

21. APHA. Standard methods for the examination of water and wastewater. American Public Health Association/ American Water Works Association/Water Environment Federation, Washington DC, USA, 2005.

22. WANG F., LUO L., LIU H., LI X., LU L., YANG X. Study on the contaminant removal efficiency of rapid infiltration pond in constructed rapid infiltration system. Environmental Pollution \& Control. 35 (5), 58, 2013.

23. XU W.L., YANG Y.N., WANG J., TANG M., JIAN Y., PEI X.J. Organic matter removal performance and mechanism in the constructed rapid infiltration system. Bulg. Chem. Commun. 48 (3), 550, 2016

24. XU W., ZHANG J., LIU Y. DEGRADATION OF ORGANIC MATTER AND AMMONIA NITROGEN IN CONSTRUCTED RAPID INFILTRATION SYSTEM. Fresen. Environ. Bull. 20 (7), 1685, 2011.

25. LIU G., ZHANG H., ZHANG X., LI W. Development of total nitrogen removing technology in constructed rapid infiltration systems. Industrial Water Treatment. 33 (3), 1, 2013.

26. XU W., CHEN J., JIAN Y., PAN Z., MOU Z. Treatment of Sewage Using a Constructed Soil Rapid Infiltration System Combined with Pre-Denitrification. Int. J. Env. Res. Pub. He. 15 (9), 2005, 2018.

27. WANG F., LUO L., LIU H., LI X., LU L., YANG X. Study on the contaminant removal efficiency of rapid infiltration pond in constructed rapid infiltration system. Environmental Pollution \& Control. 35 (5), 58, 2013.

28. FANG Q., XU W., XIA G., PAN Z. Effect of C/N Ratio on the Removal of Nitrogen and Microbial Characteristics in the Water Saturated Denitrifying Section of a Two-Stage Constructed Rapid Infiltration System. Int. J. Env. Res. Pub. He. 15 (7), 1469, 2018.

29. XU W., XU S., ZHANG J. Removal performance and mechanism of tp in improved constructed rapid infiltration system. Fresen. Environ. Bull. 22 (7), 1826, 2013.

30. WANG M., ZHANG H. EXPERIMENTAL RESEARCH ON RURAL DOMESTIC SEWAGE TREATMENT BY A STRENGTHENED CONSTRUCTED RAPID INFILTRATION SYSTEM. Fresen. Environ. Bull. 26 (5), 3550, 2017.

31. XU W., XU S., ZHANG J. REMOVAL PERFORMANCE AND MECHANISM OF TP IN IMPROVED CONSTRUCTED RAPID INFILTRATION SYSTEM. Fresen. Environ. Bull. 22 (7), 1826, 2013.

32. CHEN Y., ZHAO Z., PENG Y., LI J., XIAO L., YANG L. Performance of a full-scale modified anaerobic/anoxic/ 
oxic process: High-throughput sequence analysis of its microbial structures and their community functions. Bioresource Technol. 220 225, 2016.

33. XIA Y., HE X., FENG Z., ZHANG Q., YANG H. A comprehensive analysis of the microbial diversity in natural and engineered ecosystems based on highthroughput sequencing of 16S rRNA gene. Int. Biodeter. Biodegr. 140 160, 2019.

34. ESSA A.M., EL-GAYAR K.E., AWAD M.N., ALSHAERI M., SALAM M.A., ALNASHIRI H.M. Bacterial Purification of Sewage Wastewater Effluents and its Influence on Germination Indices of Vigna radiata and Hordeum vulgare. Pol. J. Environ. Stud. 28 (5), 3145, 2019.

35. LIU S., XI B., QIU Z., HE X., ZHANG H., DANG Q., ZHAO X., LI D. Succession and diversity of microbial communities in landfills with depths and ages and its association with dissolved organic matter and heavy metals. Sci. Total Environ. 651 (1), 909, 2019.

36. ZHANG L., SHEN Z., FANG W., GAO G. Composition of bacterial communities in municipal wastewater treatment plant. The Science of the total environment. 689 1181, 2019.

37. ZHAO D., HUANG R., ZENG J., LUO J., SHEN F., JIANG C., HUANG F., YU Z., WU Q.L. The Abundance and Community Composition of Ammonia-Oxidizing Prokaryotes in Small-Reservoir Sediments in China's Huashan Watershed. Pol. J. Environ. Stud. 25 (6), 2665, 2016.

38. ZHENG W., YU Z., XIA Y., WEN X. Influence of polyaluminum chloride on microbial characteristics in anaerobic membrane bioreactors for sludge digestion. Appl. Microbiol. Biot. 102 (2), 1005, 2018.

39. KAMIKA I., AZIZI S., TEKERE M. Comparing Bacterial Diversity in Two Full-Scale Enhanced Biological Phosphate Removal Reactors Using 16S Amplicon Pyrosequencing. Pol. J. Environ. Stud. 27 (2), 709, 2018.

40. SHEN Z., ZHOU Y., HU J., WANG J. Denitrification performance and microbial diversity in a packed-bed bioreactor using biodegradable polymer as carbon source and biofilm support. J. Hazard. Mater. 250 431, 2013.

41. SHEN Z., ZHOU Y., WANG J. Comparison of denitrification performance and microbial diversity using starch/polylactic acid blends and ethanol as electron donor for nitrate removal. Bioresource Technol. 131 33, 2013.

42. SHEN Z., ZHOU Y., HU J., WANG J. Denitrification performance and microbial diversity in a packed-bed bioreactor using biodegradable polymer as carbon source and biofilm support. J. Hazard. Mater. 250 431, 2013.

43. MA M., DU H., SUN T., AN S., YANG G., WANG D. Characteristics of archaea and bacteria in rice rhizosphere along a mercury gradient. Sci. Total Environ. 650 (1), $1640,2019$.

44. MMM K., MARCHANT H.K., KARTAL B. The microbial nitrogen-cycling network. Nat. Rev. Microbiol. 16 (5), 2018.

45. WYSZKOWSKA J. Soil contamination by chromium and its enzymatic activity and yielding. Pol. J. Environ. Stud. 11 (1), 79, 2002.

46. UDDIN M., CHEN J., QIAO X., TIAN R., ARAFAT Y., YANG X. Bacterial community variations in paddy soils induced by application of veterinary antibiotics in plantsoil systems. Ecotox. Environ. Safe. 167 44, 2019.

47. WANG L., ZHANG X., LI Y., SUN R., LIN Y., YU H., XUE Y., ZHOU X., LIU W., YAN L., ZHANG Y. The drivers of bacterial community underlying biogeographical pattern in Mollisol area of China. Ecotox. Environ. Safe. 177 93, 2019.

48. YUAN Y., LIU J., MA B., LIU Y., WANG B., PENG Y. Improving municipal wastewater nitrogen and phosphorous removal by feeding sludge fermentation products to sequencing batch reactor (SBR). Bioresource Technol. 222 326, 2016.

49. VIEIRA A., GALINHA C.F., OEHMEN A., CARVALHO G. The link between nitrous oxide emissions, microbial community profile and function from three full-scale WWTPs. Sci. Total Environ. 651 2460, 2019.

50. BENGTSSON-PALME J., MILAKOVIC M., ŠVECOVÁ H., GANJTO M., JONSSON V., GRABIC R., UDIKOVICKOLIC N. Industrial wastewater treatment plant enriches antibiotic resistance genes and alters the structure of microbial communities. Water Res. 162 437, 2019.

51. YANG Y., GERRITY S., COLLINS G., CHEN T., LI R., XIE S., ZHAN X. Enrichment and characterization of autotrophic Thiobacillus denitrifiers from anaerobic sludge for nitrate removal. Process Biochem. 68 165, 2018.

52. ZHANG L., SONG Y., ZUO Y., HUO S., LIANG C., HU C. Integrated sulfur- and iron-based autotrophic denitrification process and microbial profiling in an anoxic fluidized-bed membrane bioreactor. Chemosphere. 221 375, 2019.

53. BRAGANÇA I., MUCHA A.P., TOMASINO M.P., SANTOS F., LEMOS P.C., DELERUE-MATOS C., DOMINGUES V.F. Deltamethrin impact in a cabbage planted soil: Degradation and effect on microbial community structure. Chemosphere. 220 1179, 2019.

54. BAGADE A.V., BACHATE S.P., DHOLAKIA B.B., GIRI A.P., KODAM K.M. Characterization of Roseomonas and Nocardioides spp. for arsenic transformation. J. Hazard. Mater. 318 742, 2016.

55. ZHAO X., LIU M., LIU Y., LI Y., ZHANG S., DU K. Aerobic Degradation of 4-Monobrominated Diphenyl Ether: Identifying and Characterizing Three Strains Isolated from Populus tomentosa Phyllosphere. Pol. J. Environ. Stud. 26 (3), 1385, 2017.

56. WOŹNIAK-KARCZEWSKA M., ČVANČAROVÁ M., CHRZANOWSKI Ł., CORVINI P.F.X., CICHOCKA D. Bacterial isolates degrading ritalinic acid-human metabolite of neuro enhancer methylphenidate. New Biotechnol. 43 30, 2018.

57. LIU J., YAO J., WANG F., MIN N., GU J., LI Z., SUNAHARA G., DURAN R., SOLEVIC-KNUDSEN T., HUDSON-EDWARDS K.A., ALAKANGAS L. Bacterial diversity in typical abandoned multi-contaminated nonferrous metal(loid) tailings during natural attenuation. Environ. Pollut. 247 98, 2019.

58. van KESSEL M.A., STULTIENS K., SLEGERS M.F., GUERRERO CRUZ S., JETTEN M.S., KARTAL B., OP DEN CAMP H.J. Current perspectives on the application of $\mathrm{N}$-damo and anammox in wastewater treatment. Curr. Opin. Biotech. 50 222, 2018.

59. FU L., DING J., LU Y., DING Z., BAI Y., ZENG R.J. Hollow fiber membrane bioreactor affects microbial community and morphology of the DAMO and Anammox co-culture system. Bioresource Technol. 232 247, 2017.

60. STROUS M., HEIJNEN J.J., KUENEN J.G., JETTEN M. The sequencing batch reactor as a powerful tool for the study of slowly growing anaerobic ammonium-oxidizing microorganisms. Appl. Microbiol. Biot. 50 (5), 589, 1998.

61. LIU G., WANG J. Long-Term Low DO Enriches and Shifts Nitrifier Community in Activated Sludge. Environ. Sci. Technol. 47 (10), 5109, 2013. 
